\title{
Building a theoretical framework of message authenticity in CSR communication
}

\begin{abstract}
Purpose - This paper aims to provide an integrative theoretical framework that advances the underdeveloped stream of research that analyses how message authenticity influences the persuasiveness of corporate social responsibility (CSR) communication.

Design/methodology/approach - Theoretical and empirical literature on authenticity is reviewed to provide a comprehensive definition of message authenticity in CSR communication. An integrative theoretical framework is also developed to understand how message authenticity is enhanced through the design of informational content and it improves consumer responses to CSR communication.
\end{abstract}

Findings - The framework presented in the paper defends that message authenticity can be integrated in communication models based on three streams of research: identity-based brand management model, attribution theory and heuristic-systematic model. Consumer attributions of message authenticity can be notably improved with a message design based on CSR fit, social topic information and specificity. Authenticity improves message and source credibility by reducing consumer scepticism and enhancing their attributions of corporate expertise and trustworthiness. Indirect benefits of CSR message authenticity include increased consumer purchase, loyalty and advocacy behaviours.

Originality/value - The value of the paper resides in making the rather underdeveloped and inconclusive literature on authenticity accessible to CSR and communication researchers and practitioners. A theoretical framework is provided for further research that would contribute to improving our knowledge on the role that message authenticity plays in CSR communication. Keywords Authenticity; Corporate Social Responsibility; Message; Credibility; Consumers Paper type Conceptual paper 


\section{Introduction}

Corporate Social Responsibility (CSR) refers to all corporate activities demonstrating the inclusion of social and environmental concerns in business operations, and in interactions with stakeholders, always according to the ambition levels of sustainability of the company (van Marrewijk, 2003). Thus, by engaging in CSR companies can generate favourable consumer attitudes and better support behaviours because it strengthens the relationship with these stakeholders (Sen et al., 2006). However, consumers' low awareness of and unfavourable attributions towards companies' CSR activities remain critical impediments in companies' attempts to maximize business benefits from CSR, highlighting a need for companies to communicate these activities more effectively (Du et al., 2010; van Rekom et al., 2014).

Nevertheless, CSR is an extremely difficult message to convey (Schmeltz, 2012) and CSR communication has proved to be a double-edged sword (van Rekom et al., 2014). On the one hand, CSR communication can bring gains in loyalty and sales (Du et al., 2010). On the other hand, it frequently faces high scepticism (Alhouti et al., 2016) and companies that claim to be responsible are often subject to closer scrutiny and criticism (Nyilasy et al., 2014).

Along this line, numerous researchers have argued that the persuasiveness of CSR communication strongly depends on how the message is designed (Darley and Smith, 1993). More precisely, previous literature has demonstrated that the manipulation of key informational content within the message influences consumer responses because the message design affects consumer scepticism and attributions for the company's motivations to get involved in CSR activities (Forehand and Grier, 2003).

In this paper, I argue that the content of CSR messages can be crafted to transmit authenticity and, in so doing, companies can improve the credibility of CSR communication and, consequently, consumer responses to it. In this regard, message authenticity refers to the quality of communication and its ability to transmit that the message is true in substance (Molleda, 
2010). Thus, authenticity includes qualities of the message that refer to it as real, actual, genuine, and bona fide (i.e., being actually and exactly what is claimed).

Even though authenticity has a rich tradition in other areas of research, such as tourism (Kolar and Zabkar, 2010; Taylor, 2001; Wang, 1999) or more recently brand management and branding theory (Fritz et al., 2017; Morhart et al., 2014; Schallehn et al., 2014), it has been poorly theorized to date in the CSR communication literature (Crane and Glozer, 2016). In this regard, literature has to some extent demonstrated the influence of message authenticity on consumer perceptions of a marketing cue (Beverland, 2009). However, the present literature on authenticity fails to address the impact of perceived message authenticity on the success of CSR activities (Alhouti et al., 2016). Thus, the conceptualization and integration of this construct within a CSR communication framework will contribute to previous literature significantly. It will provide researchers and practitioners with a blueprint for establishing successful CSR strategies.

In this context, the closest attempt to describing the role of message authenticity in the CSR context was made by Alhouti et al. (2016), although their paper was empirical in nature, rather than normative and, as so, these researchers developed their research hypotheses mainly through the findings of the qualitative study that they implemented among business students. Taking the findings of Alhouti et al. (2016) as a reference for my conceptual research, in this paper I aim to go one step further in the conceptualization and discussion of message authenticity in the context of CSR and communication literature by developing a theoretical framework, based on an extensive review of literature on authenticity, CSR and communication, that contributes to previous research by (1) adequately conceptualizing message authenticity in the context of CSR communication; (2) integrating the theoretical approaches that can assist researchers and practitioners to understand the role of message authenticity in CSR communication models; (3) discussing how companies can improve 
consumer attributions of message authenticity by manipulating some key informational content of their CSR messages and (4) describing how message authenticity affects consumer responses to CSR communication. Rooted in attribution theory (Heider, 1958; Kelley, 1973) and the heuristic-systematic model (Chaiken, 1980; Chaiken et al., 1989), the theoretical framework proposed in the paper argues that message authenticity enhances the identity-based brand management model (de Chernatony et al., 2011) and, consequently, also consumer responses to CSR communication, because a message that consumers perceive as authentic positions the company as motivated by internal forces instead of external pressures, thus demonstrating a solid brand identity that improves the credibility of CSR communication and reduces consumer scepticism (Schallehn et al., 2014).

The remainder of the paper is structured as follows. First, message authenticity is theoretically defined and conceptually differentiated from related constructs explored in previous literature (e.g., credibility). Second, the theoretical framework to study and integrate this construct in the context of CSR communication is proposed. Third, the antecedents of message authenticity are explored along with its outcomes in CSR communication. The paper closes with a discussion of the most relevant conclusions, implications and gaps identified in previous literature that will stimulate further research on this novel stream of communication studies.

\section{Message authenticity: Definition and related constructs}

Due to the increasingly inauthentic or unbelievable nature of mass marketing, companies are progressively being pressured by consumers demanding greater transparency, openness and responsibility (Molleda, 2010). In this context, consumers constantly look for brands that are relevant, original and genuine, which means that they increasingly search for authenticity in companies (Morhart et al., 2014). Gilmore and Pine (2007) already acknowledged this development, stating that authenticity has overtaken quality as the prevailing purchasing 
criterion, just as quality overtook cost, and as cost overtook availability. Thus, authenticity should become central to the study and practice of modern marketing and communication management as well (Chiu et al., 2012) because, among other reasons, this attribute may represent a potential new pillar to create credibility and trust (Schallehn et al., 2014). Nevertheless, and although there is no doubt about the managerial importance of authenticity in corporate-consumer relationships, published research in the marketing and communication fields has yet not thoroughly explored the meaning of this construct (Schallehn et al., 2014) or its relevance in reference to how the CSR communication of companies is perceived by consumers and how they react to this type of messages (Crane and Glozer, 2016).

\subsection{Definition of the construct}

Authenticity refers to the quality of being true in substance, that is, being authentic is being original, first hand and prototypical (Molleda, 2010). An object is authentic if it represents the real thing, as contrasted with the copy (Schallehn et al., 2014). Therefore, authenticity is associated with attributes of an object such as genuineness, reality, fact, actuality and truthfulness (Alhouti et al., 2016; Chiu et al., 2012).

When defining the construct, three perspectives have been traditionally followed in previous literature (Kolar and Zabkar, 2010; Morhart et al., 2014): (1) objectivism, (2) constructivism and (3) existentialism. First, objectivism defends that authenticity is an objectively identifiable quality of objects that can be evaluated by experts (Kolar and Zabkar, 2010). Thus, objectivists argue that authenticity is inherent in the object itself (Schallehn et al., 2014) and that there is always an evident, objective basis or standard for judging (in)authenticity (Wang, 1999). This perspective defines the construct as objective or indexical authenticity (Morhart et al., 2014), as frequently presented in journalism research (Appelman and Sundar, 2016). On the contrary, constructivists define authenticity as a function of the perceived genuineness and positive 
valuation of an object in the mind of perceivers (Chiu et al., 2012). Thus, these researchers defend that, as long as a person subjectively believes the authenticity of an object, it exists (Lewis and Bridger, 2000). Authenticity is then defined as constructive, symbolic or iconic authenticity (Morhart et al., 2014; Wang, 1999). By conceiving authenticity as an experience or as a perception, constructivists overcome some dilemmas identified in the objectivist definition. As explained by Kolar and Zabkar (2010, p. 653), "conceiving authenticity as a phenomenon per se does not allow any possibility for managing (creating, presenting, communicating) it, so the constructivist position seems a managerially more adequate stance". Finally, from a socio-psychological and existentialist perspective, the authentic is conceptualized as self-fulfilment (Fine, 2003; Guignon, 2004). More precisely, in this third perspective authenticity is defined as the degree to which an object (e.g., person, company) is true to its own identity in the face of corrupting external pressures (Schallehn et al., 2014). For instance, when talking about people and companies, concern about fitting in and being a welladapted member of society is the definition of inauthenticity (Hartmann, 2002), while the degree to which identity is causally linked to behaviour is defined as authenticity (Schallehn et al., 2014). As a consequence, authenticity, which is defined as existentialist authenticity in this perspective, means staying true to one's self (Morhart et al., 2014).

Despite the differences, previous literature suggests that the objectivist, constructivist, and existentialist perspectives on authenticity are intertwined, and that each provides input to the conferring of authenticity to objects (Leigh et al., 2006). Along this line, Morhart et al. (2014) propose that authenticity (referred to a brand in their research) arises from the interplay of objective facts (objective authenticity), subjective mental associations (constructive authenticity) and existential motives connected to the company's identity (existential authenticity). 
Based on these ideas, in the context of CSR communication CSR message authenticity can be defined as a sense, perception or believe (Lewis and Bridger, 2000) that consumers obtain from communicational material (Chiu et al., 2012) that makes them associate objective information presented in the CSR message (Kolar and Zabkar, 2010) with the real identity of the company that gets involved with social causes and communicates its CSR activities (Molleda, 2010), perceiving the message as sincere, original, genuine, unaffected, distinct from strategic and pragmatic self-presentation (Fine, 2003) because it reflects the essence of who the company originally is (Molleda, 2010). Somehow, the definition is similar to how Alhouti et al. (2016, p. 1243) define CSR authenticity in their research: "the perception of a company's CSR actions as a genuine and true expression of the company's beliefs and behaviour toward society that extend beyond legal requirements".

\subsection{Authenticity vs. credibility}

When defining authenticity, researchers have closely linked it to related constructs such as credibility (Appelman and Sundar, 2016; Molleda, 2010; Morhart et al., 2014; Schallehn et al., 2014), which is also sometimes labelled as believability (Chiu et al., 2012). For instance, journalism researchers defend that, whereas some characteristics of a message (e.g., writing quality, balance, objectivity, professionalism, impact) are important contributors of credibility, message attributes such as accuracy, authenticity and believability, provide researchers with three nuanced views that reflect credibility (Alhouti et al., 2016; Gaziano and McGrath, 1986). Nonetheless, whereas accuracy and authenticity could be considered to be more objective, believability could be considered to be more subjective (Alhouti et al., 2016).

Therefore, it is expected that authenticity and credibility share several characteristics (Hazou, 2011), a fact that has even taken researchers to often use them as synonyms (Chiu et al., 2012; Molleda, 2010). For instance, Molleda (2010) explains that the definition of authenticity used 
in public relations research is similar to how researchers define credibility in the mass communication literature. Similarly, Chiu et al. (2012) equates authenticity to believability, defined as the extent to which corporate communications evoke sufficient confidence in corporate truthfulness to make it acceptable to consumers.

Nonetheless, in this paper I align with Hazou (2011), who considers that, while authenticity and credibility share several synonyms, they are not the same thing. More precisely, while authenticity derives from the Greek authentikós (meaning original, principal or genuine), credibility derives from the Latin credibilis (meaning to believe). Thus, while message authenticity involves a discussion of the real, credibility may be usefully conceived as a discussion of believability (Hazou, 2011). These differences imply that, under certain circumstances, even when the message is original, genuine and real (i.e., authentic), the company behind it may fail to design an effective communication strategy, thus making the message not credible for consumers. Actually, message credibility is generally agreed to result from an interaction of consumer perceptions concerning not only message characteristics (related to message content, encompassing factors such as plausibility, internal consistency, and quality) (Wathen and Burkell, 2002) but also source characteristics (e.g., expertise, trustworthiness) (Newell and Goldsmith, 2001) and consumer features (e.g., demographic characteristics, issue support, social value orientation, etc) that may affect credibility as well (Wathen and Burkell, 2002). Therefore, it may also happen that messages that fail to be authentic can still be credible for consumers if their background and previous beliefs do not make them evaluate authenticity as a necessary attribute of corporate activities and message contents.

Finally, it is also noticeable that, according to the definition provided, message credibility will always be a result of consumer perceptions (Wathen and Burkell, 2002), while message authenticity incorporates objective and existential features as well. This fact differentiates 
message credibility from the objectivist and existentialist perspectives that define message authenticity and it contributes to corroborate that authenticity and credibility should be treated as separated constructs in CSR communication models.

Nevertheless, in differentiating both constructs, researchers generally agree that authenticity is a potential new pillar, and therefore an antecedent, to create credibility (Gilmore and Pine, 2007; Schallehn et al., 2014). In this regard, credibility can be conceived as a broader and more complex construct than authenticity because it refers to more elements of the communication process (Metzger et al., 2003). More precisely, while authenticity is frequently associated only with the message content (Chiu et al., 2012), credibility can be referred to different elements of the communication process, primarily including messages and sources (Appelman and Sundar, 2016). As previously defended in communication literature, consumer attributions concerning these messages and sources are intertwined and often follow the same relational pattern, starting from the message and finishing with consumer attributions concerning the source (Homer, 1990). In this regard, previous studies have shown that the evaluation of communication messages (e.g., ads, social media content) influence corporate evaluation directly and positively (Wang, 2011). For instance, Wang (2011) argues that consumers may assess the company's communication messages to arrive at an overall assessment in evaluating the company and their trust on it. Thus, consumer perceptions of the message content and its authenticity can derive in attributions closely related to the credibility construct, such as scepticism towards the message (Mohr et al., 1998) or attributions related to corporate expertise and trustworthiness when communicating CSR activities (Newell and Goldsmith, 2001).

Figure 1 graphically represents the components of message authenticity as previously defined in this paper and their relationships to credibility in CSR communication.

\section{[Insert Figure 1 here]}


Based on these ideas, in the following sections of the paper a theoretical framework is developed that can assist future researchers and practitioners to explore and understand the role of message authenticity in CSR communication models more clearly by not only discussing how this construct relates to credibility issues, but also identifying the antecedents of message authenticity, which strongly depend on the informational content of CSR messages.

\section{How to integrate authenticity in CSR communication models: Theoretical framework}

The role of message authenticity in CSR communication models can be understood by integrating three streams of research: the identity-based brand management model (de Chernatony et al., 2011), attribution theory (Heider, 1958; Kelley, 1973) and heuristicsystematic model (HSM) (Chaiken, 1980; Chaiken et al., 1989).

The identity-based brand management model comprises two main components (de Chernatony et al., 2011): identity and image. While identity refers to the sustainable attributes of a company, which determine its essence from the perspective of internal stakeholders (e.g., employees, executives) (Meffert et al., 2012), image represents the exterior view of the company, understood as the judgemental perceptions fixed in the psyche of relevant external stakeholders (e.g., consumers) (Meffert et al., 2012). In the context of this theoretical perspective, previous literature has demonstrated the value of corporate communications in aligning corporate identity and corporate image as to improve consumer responses to the activities of the company (Balmer and Greyser, 2006).

For instance, message authenticity includes a component of existentialist authenticity (Fine, 2003; Guignon, 2004) that refers to the degree to which the message reflects the essence and real identity of the company (Molleda, 2010) even in the face of corrupting external pressures (Schallehn et al., 2014). Thus, an authentic message implies that the company is clear about what it stands for. The message presents a company that positions itself from the inside out 
versus one that panders to the latest trend (Schallehn et al., 2014), that is, it shows a company that stays true to itself (Morhart et al., 2014). In this situation, the message allows corporate identity to be translated into corporate image easily, therefore improving consumer responses significantly (Money et al., 2010). As explained by van Rekom et al. (2014), consumers will perceive as authentic what a company claims to strive for if they believe that it reflects what the company actually is. In this regard, if consumers perceive that the company's intended societal contributions flow forth from the company's characteristics (i.e., identity), they will be more inclined to believe that the CSR message fits the company and it is, therefore, authentic (van Rekom et al., 2014). In contrast, a low degree of message authenticity implies that the company is using a positioning that does not gel with its identity, and therefore, the origin of the corporate promise cannot be easily attributed to brand identity (Schallehn et al., 2014). As a consequence, the communication efforts of the company will not translate identity into image and consumer responses will fall below the desired expectations (Balmer and Greyser, 2006). This close connection among corporate identity, message authenticity and image can be explained in terms of the attribution theory originally developed by Heider (1958), which is used to understand how the causes that consumers attribute to corporate behaviour influence their subsequent attitudes and behaviours in the marketplace (Ruiz de Maya et al., 2016). Researchers generally distinguish between consumer attributions of altruistic or egoistic motives for companies to engage in a specific behaviour (Bigné et al., 2010). When consumers attribute altruistic motives to companies, their responses are improved (Becker-Olsen et al., 2006). However, the attribution of egoistic motives, which refer to the exploitative utility of the corporate behaviour, derives in a worsening of the corporate image that affects consumer responses negatively (Becker-Olsen et al., 2006). For instance, when a company takes part in CSR activities, it projects a corporate identity that is at least partly characterized by the desire for social commitment (Ellen et al., 2006). To a certain extent, the company is communicating 
that its behaviour is mostly caused by altruistic motives (Bigné et al., 2010). If adequately perceived by consumers, this corporate identity will derive into better image and consumer responses to the company.

In this context, an authentic message exhibits the behaviour of a company that is primarily led by its corporate identity (Schallehn et al., 2014). Thus, the perception of a CSR message as authentic will derive in a lower attribution of egoistic corporate motives to engage in CSR activities, therefore improving the identity-based brand management model. Nonetheless, living in a social world means the existence of external forces and social pressures that may affect corporate motivations to engage in CSR, thus moving the company far from its own identity. By presenting an inauthentic CSR message, the company will break the identity-image link, increasing consumer scepticism and affecting his/her responses negatively (Schallehn et al., 2014). Along this line, in their exploratory study, Alhouti et al. (2016) found that $28 \%$ of their respondents reported the attribution of public-serving (i.e., altruistic) motives as a relevant consequence of viewing a company's CSR communication as authentic, while $43 \%$ reported the attribution of self-serving (i.e., egoistic) motives as the main result of perceiving a company's CSR communication as inauthentic. When respondents perceived the CSR activities reported by the company as being motivated by more than just the financial bottom line, they saw the CSR message as a representation of the company's genuine desire to help others, such as when a company does not spend excessively on promoting their CSR efforts, or seems to be losing profit with their altruistic activities.

Finally, the attribution of altruistic or egoistic motives that derives from consumer interpretation of CSR message authenticity is explained by HSM (Chaiken, 1980; Chaiken et al., 1989). The HSM suggests that there are two processing modes whereby persuasion occurs (Chaiken et al., 1989). On the one hand, systematic processing is defined as a comprehensive, analytic orientation in which consumers access and scrutinize all information input for its 
relevance and importance to their judgment task, and integrate all useful information in forming their judgements. On the contrary, the heuristic mode is a type of processing that does not require much thinking effort (Chaiken, 1980). Here, consumers often pay attention to the subsidiary information so they can use simple inferential rules, schemata, or cognitive heuristics to evaluate and make a decision (Chaiken et al., 1989). More precisely, heuristic processing is based on previous experience and stored memory that are easily activated and highly accessible for people when processing information.

When applied to the CSR context, HSM postulates that, when making an ethical judgement becomes highly difficult for the consumer (e.g., deciding if CSR activities and the company that implements them are credible when the message is perceived to be inauthentic), it will increase the consumer desired sufficiency threshold, motivating him/her to process the information more actively through systematic processing and increasing the risk of suspicions appearing over the honesty of the company in its relation with CSR activities (Bigné et al., 2010). For instance, an inauthentic CSR message presents CSR activities that do not seem to correspond to the company's genuine identity. Therefore, consumers will feel motivated to devote greater thinking effort to the interpretation of the message and they will be more critical of its informational content, even anticipating egoistic motives for the company to invest in CSR activities that do not match their raison d'etre (Bigné et al., 2010). On the contrary, the perception of the message as authentic will lead consumers to process information using what is stored in their memory about the company (i.e, previous knowledge and experiences with the company) and it will make them feel more motivated to anticipate altruistic motives for the company to engage in CSR. Because the message shows high consistency between the company's identity and its CSR activities (Bigné et al., 2010), the message content will be easy to process and understand. Therefore, consumer responses to CSR communication will be better than in the eventual use of systematic processing. 
Figure 2 graphically represents the theoretical framework developed in this paper.

\section{[Insert Figure 2 here]}

\section{Antecedents of message authenticity in CSR communication}

Corporate identity is not easily visible. Hence, the question arises, how consumers arrive at the impression that a CSR message from a company is authentic (Schallehn et al., 2014). That is, which are the most significant antecedents of message authenticity? Based on the constructs most commonly discussed in previous literature, in this paper three antecedents of message authenticity are conceptualized and explored: CSR fit (Alhouti et al., 2016; van Rekom et al., 2014), social impact specificity (Alhouti et al., 2016; Pomering and Johnson, 2009a, 2009b) and social topic information (Pomering and Johnson, 2009a, 2009b).

\subsection{CSR fit}

In the process of generating positive responses to CSR communication, fit between the company and its CSR activities has been considered an especially important issue (BeckerOlsen et al., 2006; Bigné et al., 2009). CSR fit is defined as the similarity between the company (e.g., its products, branding, positioning and target audience) and the goals of the social causes involved in its CSR activities (Becker-Olsen et al., 2006). As previously defended in literature, two types of fit exist: functional and symbolic (Bigné et al., 2009). While functional fit refers to the similarity between corporate products and CSR activities, which depends on how products can adequately help to achieve the goals of CSR activities, symbolic fit refers to the similarity between corporate identity and CSR activities, which depends on the existence of coherent strategic goals of the company and its CSR activities.

The effects of CSR fit on consumer responses to CSR communication have been traditionally explained through the schemas theory (Roy and Cornwell, 2003) and the associative learning 
theory (Till and Nowak, 2000). According to these frameworks, learning is a mechanism by which consumers establish relationships among constructs to produce associative networks in their memories through which they can learn about the constructs more easily. For instance, thanks to associative networks, consumers learn about companies through their partnership with CSR initiatives and the non-profit organisations involved in them. Schemas and associative learning theory argue that the consumer learning process will always be more solid and fruitful for the company if it maintains stable and consistent links with these CSR activities and non-profit organisations, as it happens when functional or symbolic CSR fit exists. Therefore, CSR fit will enhance consumer responses to CSR communication significantly (Bigné et al., 2009). For instance, 7\% of the respondents in Alhouti's et al. (2016) research reported CSR fit as a relevant factor to perceive CSR as authentic, while $17 \%$ of the sample reported the lack of CSR fit as important to perceive CSR as inauthentic. CSR fit signals authenticity when CSR activities align with what the company sells. For instance, a company that donates its products in a CSR campaign or provides an employee volunteer program is deemed to have a good CSR fit (Alhouti et al., 2016). Fit is also perceived as authentic when CSR activities align with the company's concept or when they benefit the target market by aligning with their interests and requests (Alhouti et al., 2016). On the contrary, fit is a factor in perceptions of inauthenticity when CSR activities do not align with what the company sells, they are seen as hypocritical or the company's concept does not naturally align with philanthropy (Alhouti et al., 2016).

\subsection{Social impact specificity}

Social impact specificity is defined as consumer perceptions of how much the company is perceived to contribute to CSR relative to its size and profits, along with the degree to which CSR activities are seen to make a real and meaningful difference to society and corporate 
stakeholders (Alhouti et al., 2016). In this regard, the sheer volume of a monetary commitment to CSR is the first relevant indicator of social impact and, consequently, of authenticity. Also, if the company makes a difference with its CSR activities by demonstrating a long-term commitment or having several CSR activities in place, consumers will usually perceive CSR as authentic. Nonetheless, the amount of corporate CSR commitment is frequently difficult to observe only based on monetary contributions. Therefore, outcomes expressed in terms of impacts to society and stakeholders are also relevant to determine authenticity, because many times they are the only factual thing actually observable and open to assessment (Du et al., 2010; Pomering and Johnson, 2009a). In this regard, impact affects perceptions of inauthenticity when CSR activities are seen as ineffectual or exclude particular causes that consumers perceive as important (Alhouti et al., 2016).

To communicate social impact specificity effectively, previous researchers have recommended that companies collect and present abundant, rich, varied facts to create an authentic and compelling story that comes to life on the CSR message and meets consumer expectations (Chiu et al., 2012). In this regard, Chiu et al. (2012) defines message authenticity as some visualization of the activities of the company that is simplified by the use of concrete language, which gives consumers an association with reality and makes the information believable. In this regard, stakeholders usually demand objective cues of a factual or spatio-temporal link with the real world to form assessments of message authenticity (Beverland, 2009). In their study, Alhouti et al. (2016) relates social impact specificity to the provision of detailed information on the company's CSR investments and outcomes and they demonstrate that the effective communication of social impact specificity is deemed to an important determinant of CSR authenticity for $60 \%$ of respondents and a relevant determinant of inauthentic CSR for other $20 \%$ of their sample. 


\subsection{Social topic information}

It is also proposed that a CSR message that provides consumers with social topic information increases awareness of the social causes engaged with in the company's CSR activities. Therefore, social topic information is expected to map onto the CSR message and make it more diagnostic, accessible to consumers and, consequently, authentic (Pomering and Johnson, 2009a). Extant research points to consumers typically lacking the prior social topic knowledge needed to effectively process CSR messages, or knowledge being only moderately accessible and not easy to recall on demand (Tybout et al., 2005). By providing social topic information, CSR messages will allow consumers to draw on that information more easily in order to activate socially evaluative criteria, allowing the ease with which such information comes to mind to serve as the basis for judgement (Pomering and Johnson, 2009b).

\section{Outcomes of message authenticity in CSR communication}

Research has shown that authenticity impacts consumers positively in different contexts such as, for instance, tourism (Kolar and Zabkar, 2010; Taylor, 2001; Wang, 1999) or branding management and theory (Fritz et al., 2017; Morhart et al., 2014; Schallehn et al., 2014). This study builds on these previous literature by presuming that consumers will also react positively to companies that engage in CSR and present authentic CSR messages (Alhouti et al., 2016). In this regard, consumer responses can be classified into internal outcomes, referred to consumer attitudes, trust and attributions concerning communication and the company behind it (Du et al., 2010), and external outcomes, related to tangible responses materialized in consumer pro-company behaviours (Du et al., 2010). 


\subsection{Internal outcomes: Message and source credibility}

As previously defended in this paper, an authentic CSR message provides consumers with credible information, which helps them acquire understanding of the message context, feel more connected with it and judge the story better (Chiu et al., 2012). Along this line, attribution theory and HSM anticipate that an authentic message is associated with the attribution of altruistic motives for the company to get involved in the CSR activity, mostly because the collaboration is born from the company's stable and long-lasting identity (Schallehn et al., 2014) and, therefore, it is easy to interpret on the basis of previous knowledge about the company and its past behaviour (i.e., heuristic mode of processing information). On the contrary, when faced with an inauthentic CSR message, consumers feel motivated to scrutinize information through systematic processing. In systematic processing, consumers devote greater efforts to the interpretation of all possible data, which could lead them to be suspicious of the credibility of the message and corporate motives to engage in CSR (Obermiller and Spangenberg, 2005; Ruiz de Maya et al., 2016).

Therefore, it is expected that message (in)authenticity does not only affect consumer attributions of the message itself, but also attributions concerning the credibility of the company that communicates its CSR activities (i.e., source credibility). Source credibility refers to the degree to which consumers believe in the company's expertise and trustworthiness when communicating its CSR activities (Lafferty et al., 2002) and numerous studies have shown that this is an important dimension of credibility in CSR communication because it can get to be more persuasive than the causes themselves (i.e., messages) in influencing image, reputation, consumer attitudes and purchase behaviours (Lafferty et al., 2002). 


\subsection{External outcomes: Purchase, loyalty and advocacy behaviours}

The theoretical framework suggested in this paper also includes consumer pro-company behaviours that can derive from consumer attributions of CSR message authenticity. Along this line, previous studies have already identified consumer purchase, loyalty and advocacy behaviours as natural responses to message authenticity (Alhouti et al., 2016; Fritz et al., 2017; van Rekom et al., 2014). For instance, van Rekom et al. (2014) argue that coming across as authentic is managerially relevant because it helps maintain consumer loyalty, while consumer purchase intentions are less favourable when the company is suspected of engaging in CSR for commercial reasons, that is, when egoistic motives are attributed to the company as a consequence of inauthentic CSR messages (Lee et al., 2009). More precisely, by dealing adequately with consumer cynicism over the motives for engaging in CSR activities, the company may better manage to come across as authentic, thereby safeguarding loyalty (van Rekom et al., 2014). Similarly, Fritz et al. (2017) identify loyalty, purchase intention and the intention to recommend the company as the main behavioural consequences of authenticity identified in marketing literature.

\section{Consumer features as moderators of communication effectiveness}

The theoretical framework is completed with the identification of consumer personal features (i.e., demographic and psychological characteristics) that have the potential to affect the intensity of the authenticity-credibility link suggested in this paper. In this regard, researchers have already demonstrated that several characteristics of consumers, as the main recipients of the message, moderate the effectiveness of CSR communication (Du et al., 2010).

For instance, from a marketing perspective, researchers have devoted special attention to identifying consumer demographic characteristics to use in the segmentation of CSR markets and to learn how these characteristics might define the consumer-CSR link (Pérez and 
Rodríguez del Bosque, 2017). Demographic features are the foundation of market segmentation, and researchers have demonstrated that their study is essential to gain a better understanding of consumer attitudes and CSR perceptions. Among these features, gender, age and educational level have been reported to be the most significant characteristics influencing consumer CSR perceptions and subsequent responses to companies (Currás et al., 2014). More precisely, women (Laroche et al., 2001), older (Schloderer et al., 2014) and highly-educated consumers (Rizkallah, 2012) are believed to respond to CSR better than men, younger and less educated consumers (Pérez and Rodríguez del Bosque, 2017). Therefore, it is expected that the relationship between message content and authenticity will produce better effects in terms of credibility in CSR communication and consumer behavioural responses under the appearance of these demographic characteristics.

Additionally, consumer psychological features also play a part in determining the intensity of consumer responses to CSR communication (Du et al., 2010). In this regard, issue support (Du et al., 2010; MacInnis et al., 1991) and social value orientation (Du et al., 2010; van Lange et al., 1997) are identified as some of the most outstanding features affecting CSR communication effectiveness.

On the one hand, the extent to which consumers support CSR (i.e., issue support) will affect the effectiveness of CSR communication because it is related to consumers' motivation to process information. Research has shown that information perceived as self-relevant (vs. nonrelevant) elicits voluntary attention (Petty and Cacioppo, 1981). Therefore, since issue support reflects consumers' personal needs and values, all else equal, CSR information on initiatives that consumers deem important or personally relevant (i.e., strong support) is more likely to break the media clutter and be more effective (Du et al., 2010).

On the other hand, social value orientation is defined as the consumer stable preferences for certain patterns of outcomes for oneself and others (van Lange et al., 1997). According to this 
construct, people can be classified as prosocial, individualistic or competitive consumers. These three social value orientation types have been shown to predict a range of social behaviours. For instance, relative to individualists and competitors, prosocials are more likely to help others (McClintock and Allison, 1989). Therefore, it is expected that prosocial consumers have greater support for companies' CSR initiatives and, therefore, to be more motivated to process companies' CSR communication (Du et al., 2010).

Based on these ideas, Figure 3 shows an extension of Figure 1 by including the discussed antecedents and external outcomes of message authenticity along with consumer features as moderators in the context of CSR communication.

\section{[Insert Figure 3 here]}

\section{Conclusions}

\subsection{Conclusions and implications for CSR research}

The conceptual discussion of message authenticity presented in this paper has allowed me to identify three main components of the construct, including objectivist, constructivist and existentialist authenticity. Although most researchers have adopted only one of these perspectives to explore authenticity in companies, it is observed that the three types of authenticity are not incompatible and, therefore, an integrative definition that considers each of them as a dimension of the construct provides a clearer picture of message authenticity in CSR communication. Therefore, a first relevant implication of the study highlights that future researchers should consider and explore this multidimensional character of message authenticity in their studies to provide more solid discussions of the construct when theoretically or empirically exploring it in the context of CSR communication. 
In addition to this idea, it is also important to notice that the framework presented in the study was based on three theoretical perspectives that can assist researchers and practitioners in clearly understanding what the mental processes that lead consumers to respond to CSR communication favourably or unfavourably are. These approaches include: the identity-based brand management model, attribution theory and HSM. A close exploration of the three theories allowed me to identify consumer attributions of corporate motives to engage in CSR as the key construct that explains why message authenticity is important and how it moderates the relationship between corporate CSR-based identity and corporate CSR image. Therefore, a second relevant implication for researchers refers to these three theories as the essential framework that they should resort to when exploring message authenticity in CSR communication, while attribution theory becomes the cornerstone on which to base the theoretical arguments.

\subsection{Conclusions and implications for the practice of CSR communication in companies}

Antecedents and consequences of CSR message authenticity were also identified in the paper and relevant managerial implications for the practice of CSR and communication also derive from this discussion.

On the one hand, it would be adequate that the CSR activities selected by a company are closely linked to its own identity so that they are perceived by consumers as a natural (functional or symbolic) fit and thus more authentic than other activities that are not congruent with corporate identity. Since identity is stable over time, it is advisable that the company focuses on longterm CSR collaborations instead of over-diversifying their portfolio of activities and communication to consumers, as this would result in a less consistent image and would not allow corporate identity to be transferred to positive consumer responses adequately. 
Another implication for CSR communication concerns the design of the message content itself. Along this line, a company could benefit significantly from providing very concrete and quantitative information about the specific impact of its participation in CSR activities, instead of providing general abstract information about it or data concerning corporate inputs exclusively. In this sense, consumers want to receive concrete information about the social results obtained by the company during its collaboration in CSR activities and, therefore, providing these data will improve message attractiveness and authenticity. Companies should also provide information that generates greater consumer knowledge about CSR activities, thus improving their social awareness. Greater awareness can make it easier for consumers to process the information because they would not need to devote so much effort to understanding CSR activities, which is one of the main reasons that usually leads them to desist from processing the message.

\subsection{Limitations and future lines of research}

According to these ideas, some new lines of future research are proposed. These proposals are mostly related to empirical issues given the dearth of evidence in this regard. First, it is proposed that further research focuses on exploring the relationship between message authenticity and its antecedents and consequences empirically, because most of the studies analysed for this research were eminently theoretical or, when they were empirical, they had not explored message authenticity in a context of CSR communication. Therefore, their findings cannot be directly extrapolated to the context discussed in this paper, and new research is necessary.

It is also suggested that, when proposing these empirical works, researchers take into account the multidimensional nature of message authenticity, which implies incorporating the construct not as a global concept in causal studies, but exploring its different components in a more 
individualized way to be able to determine if each type of authenticity (i.e., objective, constructivist and existential) can play a different role in consumer responses to CSR communication.

To conclude, it is also important to notice that, as a first approach to the definition and integration of message authenticity in a context of CSR communication, the model of causal relationships among message authenticity, its antecedents and consequences presented in this paper is eminently exploratory and, as a consequence, on no account can it be considered complete or definitive. Therefore, further research should work on refining this theoretical paper through a more detailed definition of each of its constructs, as well as a deeper study of the relationships among all of them.

\section{References}

Alhouti, S., Johnson, C.M. and Holloway, B.B. (2016), “Corporate social responsibility authenticity: Investigating its antecedents and outcomes", Journal of Business Research, Vol. 69 No. 3, pp. 1242-1249.

Appelman, A. and Sundar, S.S. (2016), "Measuring message credibility: Construction and validation of an exclusive scale", Journalism \& Mass Communication Quarterly, Vol. 93 No. 1, pp. 59-79.

Balmer, J.M.T. and Greyser, S.A. (2006), “Corporate marketing. Integrating corporate identity, corporate branding, corporate communications, corporate image and corporate reputation”, European Journal of Marketing, Vol. 40 No. 7-8, pp. 730-741.

Becker-Olsen, K.L., Cudmore, B.A. and Hill, R.P. (2006), “The impact of perceived corporate social responsibility on consumer behavior", Journal of Business Research, Vol. 59 No. 1, pp. 46-53.

Beverland, M. and Luxton, S. (2005), "Managing integrated marketing communication 
(IMC) through strategic decoupling", Journal of Advertising, Vol. 34 No. 4, pp. 103116.

Beverland, M.B. (2009), Building Brand Authenticity: 7 Habits of Iconic Brands, Palgrave Macmillan, Basingstoke, Hampshire (UK).

Bigné, E., Chumpitaz, R. and Currás, R. (2010), “Alliances between brands and social causes: The influence of company credibility on social responsibility image", Journal of Business Ethics, Vol. 96 No. 2, pp. 169-186.

Bigné, E., Currás, R. and Sánchez, I. (2009), “Brand credibility in cause-related marketing: The moderating role of consumer values", Journal of Product and Brand Management, Vol. 18 No. 6, pp. 437-447.

Chaiken, S. (1980), "Heuristic versus systemic information processing and the use of source versus message clues in persuasion”, Journal of Personality and Social Psychology, Vol. 39 No. 5, pp. $752-766$.

Chaiken, S., Liberman, A. and Eagly, A.H. (1989), "Heuristic and systematic information processing within and beyond the persuasion context", in Uleman, J.S. and Bargh, J.A. (Eds.), Unintended Thought, The Guilford Press, New York, NY, pp. 212-252.

de Chernatony, L., McDonald, M. and Wallace, E. (2011), Creating Powerful Brands, Routledge, Kidlington.

Chiu, H.-C., Hsieh, Y.-C. and Kuo, Y.-C. (2012), "How to align your brand stories with your products", Journal of Retailing, Vol. 88 No. 2, pp. 262-275.

Crane, A. and Glozer, S. (2016), "Researching corporate social responsibility communication: Themes, opportunities and challenges", Journal of Management Studies, Vol. 53 No. 7, pp. 1223-1252.

Currás, R., Dolz, C. and Miquel, M.J. (2014), “Expectativas y percepciones del consumidor español respecto a la responsabilidad social: diferencias sociodemográficas”, XXVI 
Encuentro de Profesores Universitarios de Marketing, AEMARK, Elche (Spain).

Darley, W.K. and Smith, R.E. (1993), “Advertising claim objectivity: Antecedents and effects", Journal of Marketing, Vol. 57 No. 4, pp. 100-113.

Du, S., Bhattacharya, C.B. and Sen, S. (2010), "Maximizing business returns to corporate social responsibility (CSR): The role of CSR communication", International Journal of Management Reviews, Vol. 12 No. 1, pp. 8-19.

Ellen, P.S., Webb, D.J. and Mohr, L.A. (2006), "Building corporate associations: Consumer attributions for corporate socially responsible programs", Journal of the Academy of Marketing Science, Vol. 34 No. 2, pp. 147-157.

Fine, G.A. (2003), "Crafting authenticity: The validation of identity in self-taught art", Theory and Society, Vol. 32 No. 2, pp. 153-180.

Forehand, M.R. and Grier, S. (2003), "When is honesty the best policy? The effect of stated company intent on consumer skepticism”, Journal of Consumer Psychology, Vol. 13 No. 3, pp. 349-356.

Fritz, K., Schoenmueller, V. and Bruhn, M. (2017), “Authenticity in branding - Exploring antecedents and consequences of brand authenticity", European Journal of Marketing, Vol. 51 No. 2, pp. 324-348.

Gaziano, C. and McGrath, K. (1986), "Measuring the concept of credibility”, Journalism Quarterly, Vol. 63 No. 3, pp. 451-462.

Gilmore, J.H. and Pine, B.J. (2007), Authenticity - What Consumers Really Want, Harvard Business School Press, Boston, MA.

Guignon, C.B. (2004), On Being Authentic, Routledge, London.

Hartmann, G. (2002), Scars of the Spirit: The Struggle against Inauthenticity, Palgrave Macmillian, New York, NY.

Hazou, R.T. (2011), “Hypermediacy and credibility in documentary theatre: The craft of 
make-believe in Théâtre du Soleil's Le Dernier Caravansérail (2005)”, Studies in Theatre and Performance, Vol. 31 No. 3, pp. 293-304.

Heider, F. (1958), The Psychology of Interpersonal Relations, John Wiley \& Sons, New York, NY.

Homer, P.M. (1990), "The mediating role of attitude toward the ad: Some additional evidence", Journal of Marketing Research, Vol. 27 No. 1, pp. 78-86.

Kelley, H.H. (1973), “The processes of causal attribution”, American Psychologist, Vol. 28 No. 2, pp. 107-128.

Kolar, T. and Zabkar, V. (2010), “A consumer-based model of authenticity: An oxymoron or the foundation of cultural heritage marketing?", Tourism Management, Vol. 31 No. 5, pp. 652-664.

Lafferty, B.A., Goldsmith, R.E. and Newell, S.J. (2002), “The dual credibility model: The influence of corporate and endorser credibility on attitudes and purchase intentions", Journal of Marketing Theory and Practice, Vol. 10 No. 3, pp. 1-12.

van Lange, P.A.M., Otten, W., de Bruin, E.M.N. and Joireman, J.A. (1997), "Development of prosocial, individualistic, and competitive orientations: Theory and preliminary evidence”, Journal of Personality and Social Psychology, Vol. 73 No. 4, pp. 733-746.

Laroche, M., Bergeron, J. and Barbaro-Forleo, G. (2001), "Targeting consumers who are willing to pay more for environmentally friendly products", Journal of Consumer Marketing, Vol. 18 No. 6, pp. 503-520.

Lee, H., Park, T.K., Moon, H.K., Yang, Y.H. and Kim, C. (2009), “Corporate philanthropy, attitude towards corporations, and purchase intentions: A South Korea study", Journal of Business Research, Elsevier Inc., Vol. 62 No. 10, pp. 939-946.

Leigh, T.W., Peters, C. and Shelton, J. (2006), “The consumer quest for authenticity: The multiplicity of meanings within the MG subculture of consumption", Journal of the 
Academy of Marketing Science, Vol. 34 No. 4, pp. 481-493.

Lewis, D. and Bridger, D. (2000), The Soul of the New Consumer: Authenticity - What We Buy and Why in the New Economy, Nicholas Brealey Publishing.

MacInnis, D.J., Moorman, C. and Jaworski, B.J. (1991), “Enhancing and measuring consumers' motivation, opportunity, and ability to process brand information from ads", Journal of Marketing, Vol. 55 No. 4, pp. 32-53.

van Marrewijk, M. (2003), “Concepts and definitions of CSR and corporate sustainability: Between agency and communion”, Journal of Business Ethics, Vol. 44 No. 2-3, pp. 95105.

McClintock, C.G. and Allison, S.T. (1989), "Social value orientation and helping behavior", Journal of Applied Social Psychology, Vol. 19 No. 4, pp. 353-362.

Meffert, H., Burmann, C. and Kirchgeorg, M. (2012), Marketing - Grundlagen Marktorientierter Unternehmensführung, Gabler, Wiesbaden, Germany.

Metzger, M.J., Flanagin, A.J., Eyal, K., Lemus, D.R. and Mccann, R.M. (2003), “Credibility for the 21st century: Integrating perspectives on source, message, and media credibility in the contemporary media environment", Annals of the International Communication Association, Vol. 27 No. 1, pp. 293-335.

Mohr, L.A., Eroğlu, D. and Ellen, P.S. (1998), “The development and testing of a measure of skepticism toward environmental claims in marketers' communications", Journal of Consumer Affairs, Vol. 32 No. 1, pp. 30-55.

Molleda, J. (2010), “Authenticity and the construct's dimensions in public relations and communication research", Journal of Communication Management, Vol. 14 No. 3, pp. $223-236$.

Money, K., Rose, S. and Hillenbrand, C. (2010), "The impact of the corporate identity mix on corporate reputation", Journal of Brand Management, Vol. 18 No. 3, pp. 197-211. 
Morhart, F., Malär, L., Guèvremont, A., Girardin, F. and Grohmann, B. (2014), “Brand authenticity: An integrative framework and measurement scale", Journal of Consumer Psychology, Vol. 25 No. 2, pp. 200-218.

Newell, S.J. and Goldsmith, R.E. (2001), "The development of a scale to measure perceived corporate credibility”, Journal of Business Research, Vol. 52 No. 3, pp. 235-247.

Nyilasy, G., Gangadharbatla, H. and Paladino, A. (2014), "Perceived greenwashing: The interactive effects of green advertising and corporate environmental performance on consumer reactions", Journal of Business Ethics, Vol. 125 No. 4, pp. 693-707.

Obermiller, C. and Spangenberg, E. (2005), “Ad skepticism: The consequences of disbelief”, Journal of Advertising, Vol. 34 No. 3, pp. 7-17.

Pérez, A. and Rodríguez del Bosque, I. (2017), "Personal traits and customer responses to CSR perceptions in the banking sector", International Journal of Bank Marketing, Vol. 35 No. 1, available at:https://doi.org/10.1108/IJBM-02-2016-0023.

Petty, R.E. and Cacioppo, J.T. (1981), Attitudes and Persuasion: Classic and Contemporary Approaches, William C. Brown, Dubuque, IO.

Pomering, A. and Johnson, L.W. (2009a), "Constructing a corporate social responsibility reputation using corporate image advertising”, Australasian Marketing Journal, Vol. 17 No. 2, pp. 106-114.

Pomering, A. and Johnson, L.W. (2009b), “Advertising corporate social responsibility initiatives to communicate corporate image: Inhibiting scepticism to enhance persuasion”, Corporate Communications: An International Journal, Vol. 14 No. 4, pp. $420-439$.

van Rekom, J., Go, F.M. and Calter, D.M. (2014), “Communicating a company’s positive impact on society - Can plausible explanations secure authenticity?", Journal of Business Research, Vol. 67 No. 9, pp. 1831-1838. 
Rizkallah, E.G. (2012), “Brand-consumer relationship and corporate social responsibility: Myth or reality \& do consumers really care?”, Journal of Business \& Economics Research, Vol. 10 No. 6, pp. 333-344.

Roy, D.P. and Cornwell, T.B. (2003), “Brand equity’s influence on responses to event sponsorships", Journal of Product and Brand Management, Vol. 12 No. 6-7, pp. 377393.

Ruiz de Maya, S., Lardín-Zambudio, R. and López-López, I. (2016), “I will do it if i enjoy it! The moderating effect of seeking sensory pleasure when exposed to participatory CSR campaigns", Frontiers in Psychology, Vol. 6 No. 1940, pp. 1-10.

Schallehn, M., Burmann, C. and Riley, N. (2014), "Brand authenticity: Model development and empirical testing", Journal of Product \& Brand Management, Vol. 23 No. 3, pp. $192-199$.

Schloderer, M.P., Sarstedt, M. and Ringle, C.M. (2014), “The relevance of reputation in the non-profit sector: The moderating effect of socio-demographic characteristics", International Journal of Nonprofit and Voluntary Sector Marketing, Vol. 19 No. 2, pp. $110-126$.

Schmeltz, L. (2012), “Consumer-oriented CSR communication: Focusing on ability or morality?", Corporate Communications: An International Journal, Vol. 17 No. 1, pp. $29-49$.

Sen, S., Bhattacharya, C.B. and Korschun, D. (2006), "The role of corporate social responsibility in strengthening multiple stakeholder relationships: A field experiment", Journal of the Academy of Marketing Science, Vol. 34 No. 2, pp. 158-166.

Taylor, J.P. (2001), “Authenticity and sincerity in tourism”, Annals of Tourism Research, Vol. 28 No. 1, pp. 7-26.

Till, B.D. and Nowak, L.I. (2000), “Toward effective use of cause-related marketing 
alliances", Journal of Product and Brand Management, Vol. 9 No. 7, pp. 472-484.

Tybout, A.M., Sternthal, B., Malaviya, P., Bakamitsos, G.A. and Park, S.-B. (2005), "Information accessibility as a moderator of judgments: The role of content versus retrieval ease", Journal of Consumer Research, Vol. 32 No. 1, pp. 76-85.

Wang, A. (2011), “The effects of firms' advertising disclosures as a reflection of CSR practices on consumer responses", Social Responsibility Journal, Vol. 7 No. 4, pp. 592 603.

Wang, N. (1999), "Rethinking authenticity in tourism experience", Annals of Tourism Research, Vol. 26 No. 2, pp. 349-370.

Wathen, C.N. and Burkell, J. (2002), "Believe it or not: Factors influencing credibility on the Web", Journal of the American Society for Information Science and Technology, Vol. 53 No. 2, pp. 134-144. 
Figure 1. Message authenticity and credibility in CSR communication

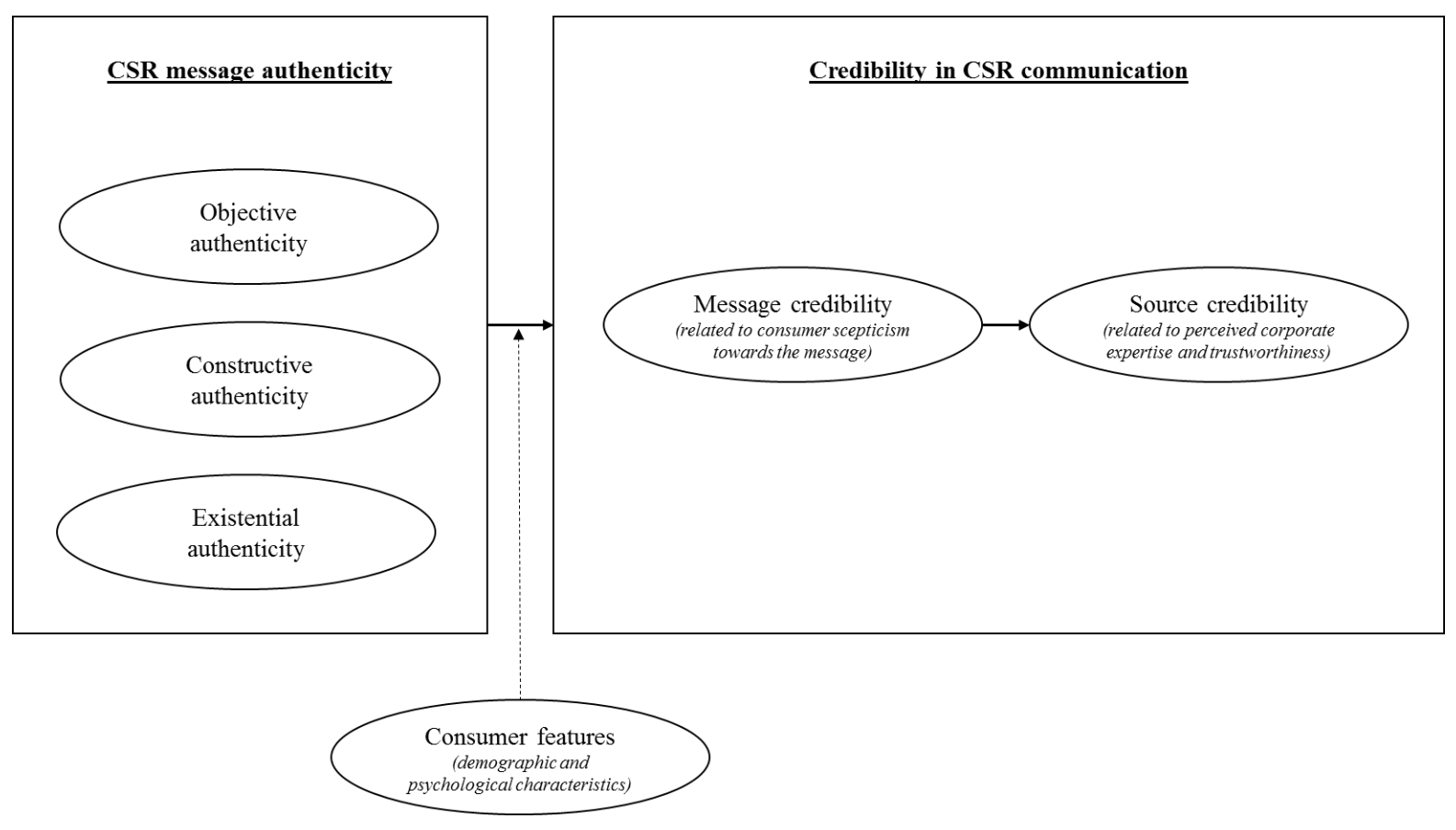

Source: Compiled by the author 
Figure 2. Theoretical framework

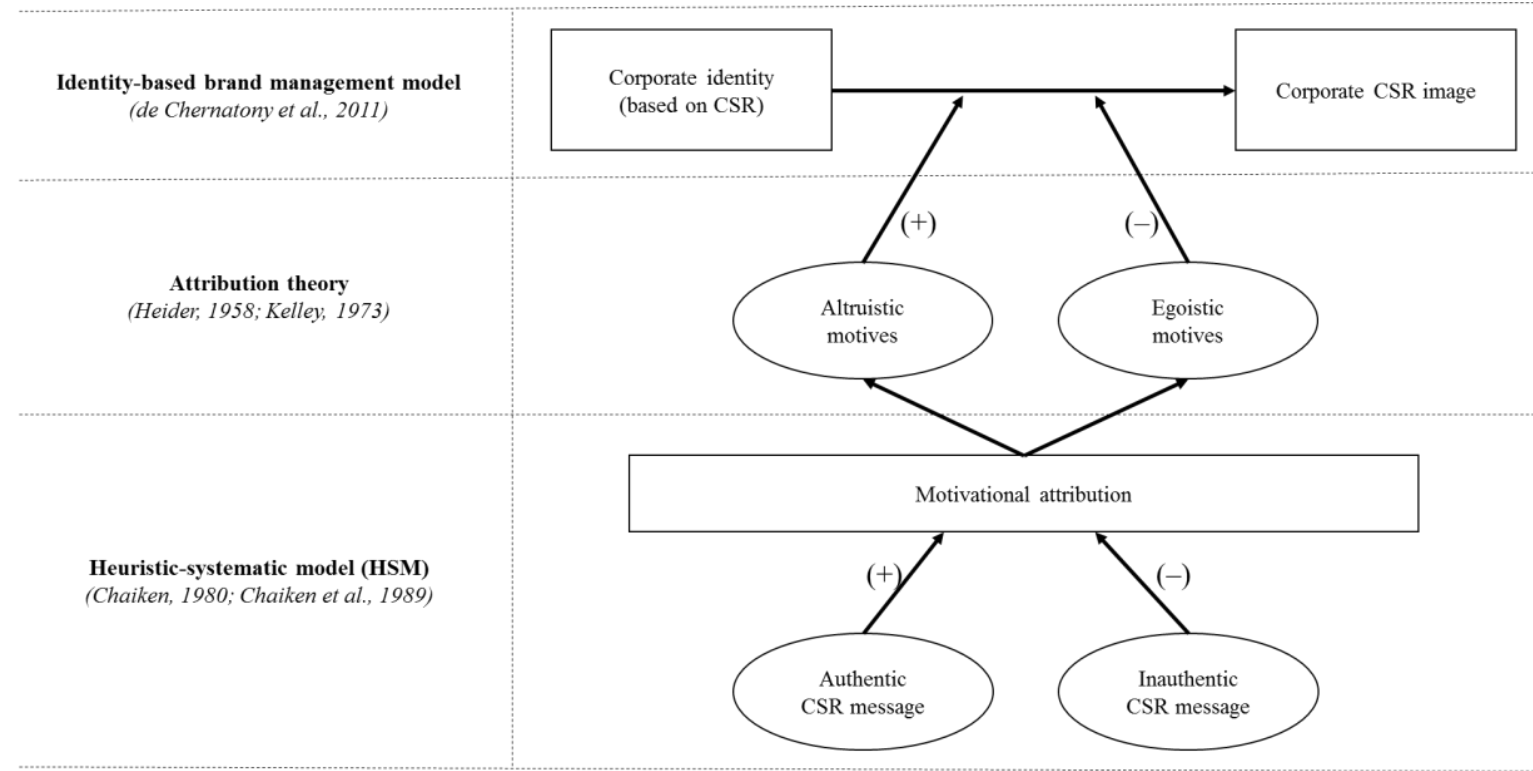

Source: Compiled by the author 
Figure 3. Antecedents and consequences of message authenticity in CSR communication
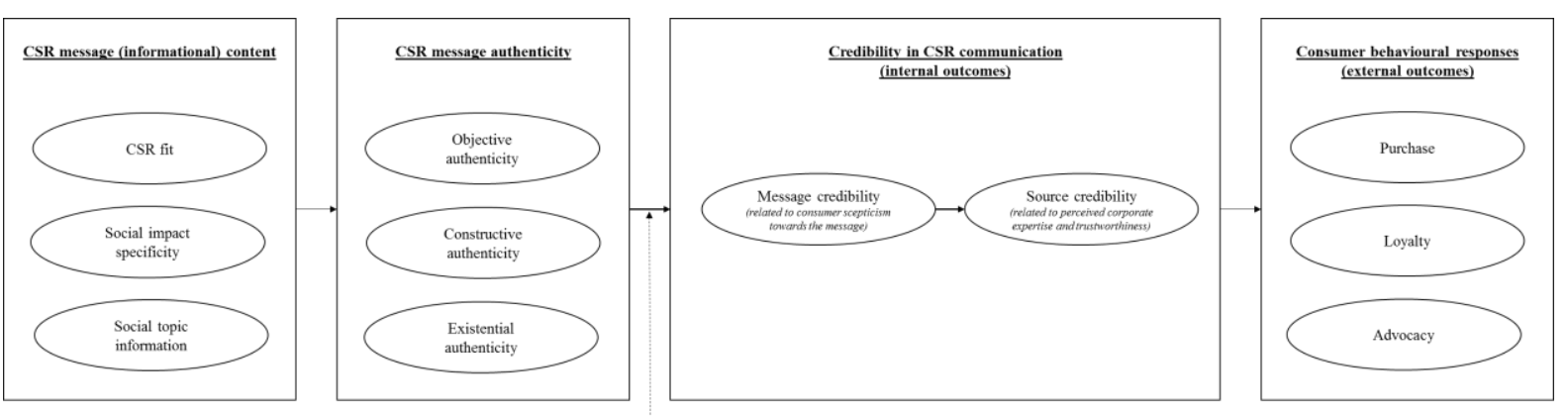
Consumer feature

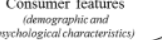

Source: Compiled by the author 